\title{
Agama dalam Eksistensi Pemahaman Tradisionalis Masyarakat Indonesia: Upaya Membedah Agama Perspektif Tradisional Ektrem dan Antisipasi Konflik Bermotif Agama
}

\author{
Hamdani Khaerul Fikri
}

Universitas Islam Negeri Mataram

Naskah diterima 19 Okt 2018, direvisi 10 Nov 2018, disetujui 27 Des 2018

\begin{abstract}
Tradisonalis understanding of the existence of religion in Indonesian society is the construction of understanding religion in General. But in this case the starting point of the religious community's understanding of Indonesia which is still very traditional in interpreting religion, then there can be remove so just with the current development of modernity that continues to evolve. See the textual basis of religion that is the hallmark of the Indonesian community, why not, because the large number of religious understanding traditionally make the society tend to think that many radical and fundamental cause of disputes between fellow human beings was no exception non islam in Indonesia also became the target of the current religious modernity also potentially give rise to religious understanding textual basis in the application seharai the days thus the author trying to browse understanding religion in a society traditionally Indonesia in various pespektif like the socio cultural, economic and political as the base material in the writing of this.
\end{abstract}

Keywords: religion, and Traditional understanding of Masyarak Indonesia

Abstrak Pemahaman agama masyarakat Indonesia yang masih sangat tradisional dalam menafsirkan agama, maka tidak bisa di lepaskan begitu saja dengan arus perkembangan modernitas yang terus berkembang. Melihat agama secara tekstual itulah ciri khas dari masyarakat indonesia, kenapa tidak, karena masih banyaknya pemahaman agama secara tradisional membuat para masyarakat cenderung berfikir fundamental dan radikal yang banyak menimbulkan perselisihan antar sesama umat manusia tak terkecuali umat non islam di Indonesia juga menjadi sasaran 
dari arus modernitas agama yang juga berpotensi menimbulkan pemahaman agama secara tekstual dalam aplikasinya seharaihari dengan demikian penulis berusaha menelusuri pemahaman agama secara tradisional dalam masyarakat Indonesia dalam berbagai pespektif seperti sosio cultural, ekonomi dan politik sebagai bahan dasar dalam penulisan ini.

Kata Kunci: Agama, dan Pemahaman Tradisional Masyarak Indonesia

\section{A. PENDAHULUAN}

Rasanya tidak terlalu berlebihan bila para pengungsi yang menjadi korban berbagai konflik pada beberapa tahun ini yang seakan mereka menjadi tamu pada negaranya sendiri. Berbagai konflik agama, seakan menjadi warna kegundahan masyarakat yang menadi sasarannya. Negara ini memang sudah merdeka, tetapi para pengungsi tidak ubahnya seperti dalam suasana perang: di usir dari tempat tumpah darahnya sendiri, kemudian berkelana ke tempat lain yang tidak dikenal. para pengungsi itu meninggalkan kampung halamannya sendiri sambil memutuskan tali hubungan psikologis dengan nenek moyang mereka.

Para pengungsi tidak lagi menziarahi para orang tua, sanak keluarga, dan leluhur mereka, karena telah disekta oleh suku, agama, ras, dan antargolongan. Para pengungsi bersimbah air mata menyaksikan hasil jerih payahnya di bumi hanguskan oleh saudara mereka sendiri sesama anak bangsa serta dipaksa berpisah dengan sanak saudara dan para tetangga yang bisa di ajak bercengkrama dan bersenda gurau. Secara tertulis mereka adalah warga resmi yang memiliki hak yang sama dengan yang lainnya. Tetapi,secara sosial politik, sosial ekonomi, dan sosial budaya, hampir tidak ada satupun hak warga negara yang masih melekat pada diri mereka. hak-hak itu seolah terbawa serta oleh kepergian mereka dari kampung halaman kebanggaan mereka sendiri (Al-Munawar, 2004:223-225).

Ketika konflik bermunculan atas kasus agama maka bagi kita menjadi masalah yang kompleks. Banyaknya kasus yang bermotif 
agama nampaknya akan selalu bergulir selagi zaman akan selalu menuntut perkembangan kearah yang semangkin modern. Telorensi (tasamuh) antar sesama bukan lagi menjadi sifat dari karakter manusia beragama pada saat ini.

Berfikir yang terlalu tradisonal dan sangat fundamental terhadap tafsiran keagamaan akan semakin membuat fanatisme agama yang sangat berlebihan. Salah pemahaman masyarakat dalam implementasi agama dalam perspektif sosio-kultural adalah seperti yang kita lihat dalam kasus-kasus yang telah berkembang selama ini. Salah satunya adalah kasus pembantaian satu kelompok terhadap Ahmadiyah yang terjadi pada tahun 2011. Dilanjutkan dengan kasus pembakaran pondok pesantren dan mushalla di kecamatan Omben Sampang Madura yang di klaim oleh sebagaian kelompok Sunni mereka beraliran Syiah. Hal ini di sebabkan karena norma-norma yang tradisional sudah mendarah daging dan menjiwai (sudag internalized) sehingga sukar sekali untuk mengubah norma-norma yang sudah demikian meresapnya dalam jiwa generasai tersebut.

Suatu masyarakat yang terkena proses akulturasi selalu ada kelompok individu yang sukar sekali atau bahkan tak dapat menyesuaikan diri dengan perubahan-perubahan yang terjadi. Perubahan-perubahan dalam masyarakat di anggap oleh golongan tersebut sebagai situasi kritis. Seperti terjadi konflik agama dan ras budaya yang masing-masing menjustifikasi sesama sehingga hal ini bisa membahayakan keutuhan masyarakat (Soekanto, 2007:169). Baik dalam agama maupun dalam kelompok atau ormasi lainnya.

Artikel ini berjudulAgama dalam Eksistensi Pemahaman Tradisionalis Masyarakat Indonesia: Upaya Membedah Agama Perspektif Tradisional Ektrem dan Antisipasi Konflik Bermotif Agama.Pemahaman agamamasyarakat Indonesia masih sangat tradisional dalam menafsirkan agama, maka tidak bisa dilepaskan begitu saja dengan arus perkembangan modernitas yang terus berkembang. Melalui studi pustakadalam pespektif sosio-cultural, ekonomi dan politik. Artikel ini mengemukakan bahwa 
masyarakat memahami agama secara tekstual, sebab banyaknya pemahaman agama secara tradisional cenderung berfikir fundamental dan radikal. Hal demikian dapat menimbulkan perselisihan antar sesama umat beragama di Indonesia.

\section{B. PEMBAHASAN}

\section{Agama dan Tradisionalisme}

Peradaban islam di Indonesia yang semakin terpuruk saat ini akan semakin melukai hati bangsa sebagai negara yang sangat beragam. Disamping itu juga paradigma tradisional masyarakat Indonesia yang berhaluan agama islam akan semakin mencederai nilai-nilai islam yang sangat mengahargai perebedaan itu. Islam yang di wahyukan oleh Tuhan kepada Muhammad SAW. Telah membawa bangsa Arab yang semula terbelakang, bodoh, tidak terkenal, dan di abaikan oleh bangsa-bangsa lain. Menjadi bangsa yang maju. Ia dengan cepat bergerak mengembangkan dunia, membina satu kebudayaan, dan peradaban yang sangat penting artinya dalam sejarah manusia hingga saat sekarang. Bahkan, pada mulanya bersumber pada islam (Badri, 2010:2).

Landasan "tradisional of relegion" adalah sebuah kebudayaan yang di bangun (construct) atas dasar sejarah yang lahir dari tradisi hegemoni agama nenek moyang yang belum kenal dengan modernisasi agama. Peranan agama menjadi sangat penting ketika agama dianut oleh sekelompok manusia yang terkait dengan kegiatan pemenuhan kebutuhan hidupnya. Dalam kondisi semacam itulah agama telah menjadi sosial budaya bahkan pula menjadi tradisi manusia, sehingga agama dan masyarakat mempunyai hubungan timbal balik. Dengan demikian maka etos yang menjadi pedoman dalam pranata telah dipengaruhi dan di arahkan oleh nilai agama itu.

Persentuhan ini bukan saja dapat melahirkan sebagai corak keberagaman dalam berbagai sekte dan pengalaman agama tetapi juga berdimensi kepentingan sosial, budaya, politik, ekonomi dan sebagainya, sehingga agama menjelma kedalam bentuk values yang terkait dengan struktur kelas sosial status yang memberi 
makna dalam kehidupan social budaya (Collins, 1986:7). Eksistensi dari agama tradisional (tradisionalism of religion) sampai sekarang terus berkembang, hingga pemahaman yang semakin fundamental sangat berpotensi menimbulkan konflik antar sesama umat khusunya umat islam di Indonesia. Dengan demikian apabila agama telah di aktualisasikan dalam kehidupan masyarakat, sehingga agama kemudian terintegrasi kedalam sistem nilai sosial budaya yang kemudian bersentuhan melalui proses sosial dengan elemen-elemennya maka berarti telah bersentuhan dengan realitas kehidupan masyarakat yang bersifat fisik, sosial, budaya ekonomi politik maupun kebudayaan integratif yang bersifat fundamental, seperti bersentuhan dengan kebutuhan moral beradab dan bersatu (Ishomuddin, 1997:208). Sekilas tentang eksistensi agama dalam pemahaman tradisional

Tradisionalisme agama sebagai kearifan lokal mengidentikkan Islam dengan tradisi lokal sudah dilakukan sejak dahulu kala. Kaum orientalis zaman dahulu tidak terbiasa membedakan antara Islam dan Arab, sehingga Islam disebut dengan istilah-istilah lain yang sebenarnya mengacu pada bangsa atau wilayah, misalnya "Saracens" atau "Turks". Jadi, menurut mereka, Islam adalah agamanya

bangsa Arab. Lambat laun, mereka pun menyadari bahwa definisi ini tak dapat dipertahankan, karena muallaf terus bermunculan dari seluruh penjuru dunia. Maka mereka mengajarkan kepada murid-muridnya (kaum sekularis-pluralis-liberalis) bahwa Islam memang bukan agama bangsa Arab, namun dalam ajaran agama Islam yang telah kita kenali ini terdapat begitu banyak aturanaturan yang diadaptasi dari tradisi-tradisi Arab. Dengan kata lain, Islam tidak identik dengan Arab, namun Islam bisa (dan telah) terinfiltrasi oleh corak budaya Arab.

Muncullah gagasan berikutnya. Kalau Islam bisa 'diwarnai' dengan budaya Arab, mengapa kita tidak ikut 'mewarnai' Islam dengan budaya Indonesia? perselingkuhan' semacam ini tetaplah problematis. Sebab, kaum sekularis mengkritik sebagian ajaran Islam karena dianggapnya tidak rasional, namun sebaliknya 
mereka justru tiarap ketika menghadapi tradisi-tradisi lokal yang lebih tidak rasional lagi. Sebagian di antara mereka mengatakan bahwa zikir, apalagi berjamaah, adalah 'pelarian' bagi orang-orang yang tak mampu menyelesaikan persoalan-persoalan hidupnya dengan akal sehat. Tapi atas nama 'kearifan lokal', mereka anggap masuk akal saja tradisi berendam ramai-ramai di sungai untuk membersihkan diri dari segala sifat buruk atau dalam rangka menyambut bulan suci Ramadhan. Ada juga yang bilang bahwa merujuk pada syariat Islam itu identik dengan melarikan diri karena tak mampu lagi menggunakan kekuatan akalnya untuk memecahkan masalah-masalah sosial kemasyarakatan. Tapi terhadap tradisi memohon-mohon di depan kubur, upacara memandikan keris atau berebut kue dan makanan dari keraton sebagai simbolisme 'rebutan berkah', mereka diam saja. Sematamata karena sebagian masyarakat Indonesia memang terlanjur cocok dengan tradisionalisme.

Demi tradisi lokal, agama pun dibikin 'lokal', dan dilarang menjadi universal. Memang tepat kiranya jika fenomena ini kita sebut dengan istilah lokalisasi agama', karena lokalisasi memang identik dengan pelacuran, dan tawar-menawar dengan 'aqidah tidak lain adalah pelacuran, aqidah itu sendiri.Dalam kaitan ini kita bisa berkaca pada sejarah panjang Islam di Indonesia, yaitu pertemuan antara "teologi Islam Arab" dengan "teologi lokal nusantara" yang memungkinkan terjadi dialektika secara terbuka, sehingga Islam benar-benar menjadi agama sejarah yang dihayati, dipikirkan, dan dipraktikkan masyarakat. Atas dasar itu, klaim bahwa Islam di Jawa misalnya, kurang asli dan kurang otentik dibanding Islam di Timur Tengah, menjadi tidak relevan.

\section{Pemahaman Tradisional Masyarakat Indonesia}

Kaum tradisional agama sebagai basis dalam bertindak adalah agama yang sangat samawi (wahyu) Munir Mulkhan, dalam bukunya yang mengatakan Kelompok tradisionalis sering dikategorikan sebagai kelompok Islam yang masih mempraktekkan beberapa praktek tahayyul bid'ah, khurafat, dan 
beberapa budaya animisme, atau sering diidentikkan dengan ekspresi Islam lokal, sementarakelompok modernis adalah mereka yang sudah tidak lagi mempraktekkan beberapa haldi atas. Akan tetapi kategorisasi ini menjadi kurang tepat ketika ditemukan adanya praktek budaya animisme yang dilakukan oleh kalangan muslim modernis, seperti yang pernah diungkap oleh Munir Mulkhan dalam penelitiannya tentang Islam murni dalam masyarakat petani. Di dalam penelitiannya ia menemukan adanya empat varianmasyarakat Muhammadiyah; yaitu Islam murni (kelompok al-Ikhlas), Islam murni yang toleran terhadap praktek TBC (kelompok Kyai Dahlan), Islam neo-tradisionalis (kelompok MUNU, Muhammadiyah-NU), dan Islam neosinkretis (kelompok MUNAS,Muhammadiyah-Nasionalis) Mereka adalah kelompok yang membaca dan belajar "kitab kuning", termasuk karya alGhazali dan ulama' fiqh klasik, dan tokoh-tokoh sufi pada zaman pertengahan Islam tradisional berarti kecenderungan untuk melakukan sesuatuyang telah dilakukan oleh pendahulu, dan memandang masa lampau sebagai otoritasdari segala bentuk yang telah mapan.

Tradisonalime agama sebagai fitur radikal dan seni berfikir Kesenian wujud, berkembang dan menjadi turun temurundalam tradisi-tradisi sosial masyarakat. Kesenian adalah milik masyarakat, dilihat sebagai cara hidup yang bertalian dengan keindahan dari para ahli masyarakat. Bukan hanya seni yang kita lihat dalam keseharaian, namun dalam agama pun terdapat seni yang menjung tinggi nilai-nilai agama seperti seni dan budaya islam pada Negara-negara arab dan timur tengah pada umumnya.

Melihat agama islam di indonesia sebagai agama produksi dalam sejarah nenek moyang yang di bawa oleh pendatang, sejauh itu pula Achamad Jainuri, memandang kaum tradisionalis adalah mereka yang pada umumnya di identikkan dengan ekspresi Islam lokal, serta kaum elit kultur tradisional yang tidak tertarik dengan perubahan dalam pemikiran serta praktik Islam. Sementara itu, tradisionalisme adalah paham yang berdasar pada tradisi.Lawannya adalah modernisme, liberalisme, radikalisme, 
dan fundamentalisme. Berdasarkan pada pemahaman terhadap tradisi di atas, maka tradisionalisme adalah bentuk pemikiran atau keyakinan yang berpegang pada ikatan masa lampau dan sudah dipraktekkan oleh komunitas agama.

Seiring dengan semakin realistisnya budaya agama di Indoensia maka ada beberapa fitur ideologisasi radikal masyarakat Islam Indonesia. Menurut Davis Erik dalam bukunya "Ideologi Social Class, And Islmic Radicalism In Modern Egypt" Yaitu salah satu fitur terpenting dari ideology islmisasi radikal adalah karakter totalitarian atau holistik, sebagai antithesis dari ideologi barat sekuler. Ideology islmisme radikal lebih menekankan visi kesatuan Islam sebagai doktrin sekaligus praktik sosial. Islam menurut para ideologi radikal, meliputi seluruh aspek kehidupan yang mencakup bukan saja persoalan akhirat tetapi juga persoalan duniawi. Doktrin ini sejalan dengan konsep islam sebagai 3 D sebagaimana diusulkan oleh mayoritas ideologi radikal (Din/ Agama, Dunya/ Dunia, dan Daulah/ Negara). Dia tidak hanya terdiri dari unsur-unsur ibadah-ritual semata, tetapi juga sebuah pandangan hidup total yang memberikan petunjuk di seluruh aspek kehidupan seperti politik, ekonomi, dan sosial budaya.

Fitur selanjutnya adalah pemahaman keagamaan yang literal. Makna literal disini ialah kecendrungan kelompok radikal untuk menyuarakan apapun secara apa adanya tanpa upaya pemahaman yang memadai terhadap konteks. Interpretasi tidak di perlukan sepanjang tetx suci menegaskan secara ekspilsit apapun yang di perintahkan. Tingkat kesalihan di tentukan salah satunya oleh sejauhmana seseorang menganut secara total-literal terhadap ketentuan yang sudah di ajarkan oleh Islam dalam seluruh aspek kehidupan. Di lain pihak, mereka cenderung menghindari apapun yang di anggap tidak termaktub di dalam kitab suci agama, AlQur'an dan Hadist.

Fitur ketiga dari ideologi islmisme radikal ialah tafsir keagamaan yang cenderung simbolik. Farme mengatakan dalam tafsir semacam ini, aspek yang lebih mengemuka adalah mindset 
berfikri yang dipenuhi dengan permainan simbol ketimbang esensi persoalan. simbol menjadi varian determinan dalam keberagaman kaum radikal. Hal ini berimbas pada cara pandang atau berfikir kelompok radikal atas segala aspek kehidupan segala sesuatu harus di kaitkan dengan simbol. Cara berfikir simbolik ini berimplikasi pada munculnya kecendrungan berfikir simplikastif dan reduksionestik dalam bahasa sehari-hari disebut "serampangan" atau hantam kromo". Hal ini merupakan akibat dari minimnya cara berfikir kritis dalam merespon apapun yang mereka lihat dan baca.

Kaum tradisionalis di Indonesia adalah mereka yang konsisten dalam berpegang teguh pada mata rantai sejarah serta pemikiran ulama-ulama terdahulu yang masih menganut teologi tradisional. Adapun aliran yang tergolong aliran teologi tradisional adalah Asy'ariyah dan Maturidiyah Bukhhara yang kurang memberikan peran yang kuat pada usaha manusia (Mubarok, 2006:11), dalam perilaku keberagamaannya. Konkritnya, memegang dan mengembangkan ajaran fiqh scholastik madzhab empat.

Sementara itu, aliran teologi tradisional akan menyatakan bahwa penyebab perubahan masyarakat (sosial) adalah kehendak tuhan (jabari). Terhadap msalah ini tampaknya M.Quraisyi Shihab mencoba memberikan jalan keluar walau pada ujungnya tetap lebih cenderung pada aliran teologi yang lebih rasional. Ia menjelaskan bahwa ayat Inna Allaha la yughayyiru ma bi qaumin hatta yughayyiru na bi an fusihim (sesungguhnya Allah tidak mengubah keadaan suatu kaum/ masyarakat sampai mereka mengubah terlebih dahulu apa yang ada pada diri mereka;) sikap mental mereka mengandung pengertian tentang adanya dua macam perubahan dengan dua pelaku. Tradisionalisme sebagai antisipasi modernisasi.

\section{KESIMPULAN}

Khusus bagi negara berkembang seperti Indonesia, pada masa depan ini akan mempunyai tiga ciri utama. Pertama, masyarakat Indonesia berubah dari masyarakat agraris menjadi masyarakat 
industri. Kedua, globalisasi informasi, dan ketiga, semakin tingginya tingkat intelektualitas terutama di kalangan kaum muda. Kondisi yang akan di alami indonesia tersbut bukannya tidak ada tantangan yang akan di hadapi, khusunya bagi para agamawan. Setidaknya tantangan akan dihadapi semacam itu diperkirakan antara lain sebagai berikut:

Pertama masyarakat akan jauh dari agama, seperti halnya masyarakat barat yang maju dan modern, masyarakat agraris menjadi masyarakat industri akan jauh dari agama. Hal ini didasarkan atas kenyataan bahwa masyarakat agraris sangat mengantungkan kehidupannya kepada alam. Faktor-faktor yang di luar kemampuan mereka untuk mengatasinya seperti kemarau panjang, banjir besar, secara psikologis membuat masyarakat agraris cenderung taat kepada agama. Mereka selalu mendekatkan diri pada Tuhan dengan berharap diselamatkan dari berbagai bencana. Sebaliknya masyarakat industri akan tidak terlalu bergantung kepada alam. Mereka lebih otonom dalam mengatasi perekonomian yang di perlukan dalam memenuhi kebutuhannya.

Kedua, masyarakat lebih cendrung berprilaku tidak sopan. Kecendrungan ini muncul antara lain diakibatkan oleh derasnya globalisasi informasi. Semakin canggih sarana informasi berupa media cetak dan elektronik, dimungkinkan budaya lain yang negatif sukar diadakan sensor dan sebaliknya akan mudah di baca dan dilihat di tempat tinggal masing-masing penduduk. Berita ataupun hiburan yang berisi semacam kejahatan atau prilaku menyimpang lain yang di perdengarkan, ditulis, atau digambar (gerak atau diam) media tersebut akan banyak dinikmati.

Ketiga, masyarakat tidak mudah menerima pendapat orang lain, guru agama sekalipun, kalau suatu pendapat tidak diberikan argumentasi yang rasional yang dapat diterima oleh pihaknya, hal semacam ini antara lain diakibatkan oleh semakin luasnya ilmu pengetahuan dan teknologi.

Jika agama tradisional sebagai antisipasi terhadap arus modernitas maka tidak bisa dimungkinkan akan terjadi yang namanya agama ektrim. Dalam hal ini toleransi antar sesama 
nampaknya tidak akan jelas jenis kelaminnya jika hanya para kaum trasionalis tetap dalam pendiriannya. Masalah akan lebih sensitif bagi siapun yang menganut agama. Masalah ini ialah orang yang selalu menganggap dirinya benar, bahwa orang yang bertentangan dengan dirinya adalah salah dan masalah ini akan mengarah ke fanatisme dan extremisme.

Umat islam menyakini bahwa perbedaan agama itu ada berkat kehendak dan kearifan Tuhan seperti dalam firmanya surat Huud ayat 118-119. Artinya : Jikalau Tuhanmu menghendaki, tentu dia menjadikan manusia umat yang satu, tetapi mereka senantiasa berselisih pendapat, (Huud ayat 118). Artinya: Kecuali orangorang yang diberi rahmat oleh Tuhanmu. dan untuk itulah Allah menciptakan mereka. kalimat Tuhanmu (keputusan-Nya) Telah ditetapkan: Sesungguhnya Aku akan memenuhi neraka Jahannam dengan jin dan manusia (yang durhaka) semuanya. (Huud Ayat 119).

\section{DAFTAR PUSTAKA}

Ahimsa-Putra, H.S.2003. “Dari Ekonomi Moral, Rasional, ke Politik Usaha" dalam Ekonomi Moral, Rasional dan Politik dalam Industri Kecil di Jawa, Ahimsa-Putra (ed.) Yogyakarta: Kepel Press bekerja sama dengan Yayasan Adikarya Ikapi dan Ford Foundation.

1978/ 1979.Adat dan Upacara Perkawinan Daerah Nusa Tenggara Barat, Jakarta: Proyek Penelitian dan Pencatatan Kebudayaan Daerah.

1983/ 1984. Upacara Tradisional dalam Kaitannya dengan Peristiwa Alam dan Kepercayaan di Nusa Tenggara Barat, Mataram: Proyek Inventarisasi dan Dokumentasi Kebudayaan Daerah Nusa Tenggara Barat. 1988.Sejarah Daerah Nusa Tenggara Barat, Jakarta: Proyek Inventarisasi dan Pembinaan Nilai Budaya. 
2006. Strukturalisme Levi-Strauss, Mitos dan Karya Sastra, Yogyakarta: Kepel Press.

2007.Antropologi Struktural, (Terjemahan), Yogyakarta: Kreasi Wacana.

2007. Patron dan Klien di Sulawesi Selatan-Sebuah Kajian Fungsional-Struktural, Yogyakarta: KEPEL Press.

1991.Upacara Tradisinal Sorong serah dan Nyondol Dalam Adat Perkawinan Sasak di Lombok, Mataram: Proyek Inventarisasi dan Pembinaan Nilai-Nilai Budaya.

Geertz, C. 1992. Tafsir Kebudayaan, (Terjemahan), Yogyakarta: Kanisius.

Kumbara, A.A. N.A. 2008. Konstruksi Identitas Orang Sasak Di Lombok Timur, Nusa Tenggara Barat, Yogyakarta: Disertasi Pascasarjana Program Studi Antropologi UGM.

Levi-Strauss, C. 1966. The Savage Mind, Chicago: The University of Chicago Press.

Mauss, M. 1992. Pemberian: Bantuk dan Fungsi Pertukaran di Masyarakat Kuno, (Terjemahan: Parsudi Suparlan (ed.), Jakarta: Yayasan Obor Indonesia. 